\section{Sylvatic rabies and the perception of vampire bat activity in communities in the Ecuadorian Amazon}

\author{
Rabia selvática y percepción de la actividad \\ del murciélago vampiro en las comunidades \\ amazónicas ecuatorianas
}

\author{
Raiva silvestre e percepção da atividade de \\ morcegos vampiros em comunidades \\ amazônicas equatorianas
}

\author{
${ }^{1}$ Ministerio de Salud Pública \\ de Ecuador, Quito, Ecuador. \\ 2 Red GRAAL, Quito, Ecuador. \\ 3 Universidad Internacional \\ de Ecuador, Quito, Ecuador. \\ 4 Departamento de \\ Enfermería, Universitat \\ Autònoma de Barcelona \\ Barcelona, España. \\ 5 Universidad Yachay, Quito, \\ Ecuador. \\ Correspondence \\ N. Romero-Sandoval \\ Ministerio de Salud Pública \\ de Ecuador. \\ Av. Simón Bolivvar y Jorge \\ Fernández s/n, Quito, \\ Ecuador. \\ natalia.romero.15@gmail.com
}

\begin{abstract}
An outbreak of sylvatic rabies was reported in indigenous communities located in the Ecuadorian Amazon in November 2011. The objective of this study was to analyze family dwelling characteristics and other sociodemographic factors associated with the perception of an increase in hematophagous bat bites in humans and domestic animals to assist the implementation of intervention policies in the region. A total of 381 households from communities covered by the outbreak response activities were surveyed. Despite being associated with poorer dwelling conditions, the possession of domestic animals is associated with the perception of an increase in bat bites among animals. Better dwelling conditions, use of protective measures, access to electricity, and no domestic animals are variables associated with the perception of a rise in attacks on humans. The analysis of perceptions of bite frequency is fundamental to improve the effectiveness of vaccination programs and strategies to promote the adoption of preventive measures against rabies among the population.
\end{abstract}

Chiroptera; Rabies; Disease Outbreaks

\author{
Natalia Romero-Sandoval 1,2 \\ Natalia Escobar 3 \\ Mireia Utzet 2,4 \\ Maria Feijoo-Cid 2,4 \\ Miguel Martin 2,4,5
}

\section{Resumen}

En Ecuador se reportó un brote de rabia selvática en comunidades indígenas amazónicas en noviembre de 2011. El objetivo del trabajo fue analizar las características de las viviendas de las familias, añadiendo aspectos sociodemográficos asociados a la percepción del aumento de mordeduras de murciélagos hematófagos en humanos y en ganado, con el fin de implementar políticas de intervención en la zona. Fueron encuestados 381 jefes de familia de las comunidades incluidas en el programa de primera intervención de vacunación. La posesión de ganado conduce a un aumento en la percepción de las mordeduras de murciélago en los animales y estas personas tienen casas con las peores condiciones de vivienda, donde pueden entrar y habitar murciélagos, mientras que las familias que tienen mejores condiciones de vivienda, con protección, electricidad y sin ganado perciben un aumento en los ataques a humanos. El análisis de la percepción de frecuencia de mordeduras es fundamental para lograr una adhesión a las medidas de prevención y vacunación.

Quirópteros; Rabia; Brotes de Enfermedades 


\section{Introduction}

The vampire bat species Desmodus rotundus is responsible for the highest incidence of human rabies transmissions caused by hematophagous bats in Brazil, Colombia and Peru 1,2,3. The distribution of this species is largely concentrated in the Ecuadorian Amazon, where a human rabies outbreak between 17 November and 7 December 2011 resulted in 11 deaths, nine of which were children under 15 years of age. This triggered an intensive government response leading to a declaration of sanitary emergency ${ }^{4}$ and a study of the factors associated with bat bites in the affected area 5 . The only previous report on outbreaks of sylvatic rabies transmitted by vampire bats in the Ecuadorian Amazon was produced in 20076 and involved cases in communities near the border with Peru.

Considering the low incidence of the disease at national level (based on this outbreak the national incidence rate is 0.76 per million population), rabies is an apparently low priority in Ecuador. However, in the context of the affected communities and age group, the incidence rate is dramatically higher: for example, in the community of Tarimiat rabies was responsible for $15 \%$ of deaths among children under 15 years of age.

Lack of knowledge of the rabies problem and the perception that the risk of contracting the disease is low has resulted in an absence of primary preventive practices among high risk populations, even when the rabies vaccine is readily available 7 .

The objective of this study was to analyze the perceptions of heads of households in communities at a high risk of attack by vampire bats regarding the association between vampire bat activity and dwelling conditions and the presence of domestic animals.

\section{Materials and methods}

Taisha Canton is located $68 \mathrm{~km}$ from Macas, the provincial capital of Morona Santiago in the Ecuadorian Amazon. The region's indigenous population is highly dispersed (density $=2$ people/ $\mathrm{km}^{2}$ ). Communities are isolated and can only be reached on foot, involving a journey of several days, plane, or canoe.

Fifteen communities were selected for this study that satisfied one of the following criteria: occurrence of deaths due to sylvatic rabies; costs and access conditions were compatible with outbreak emergency response criteria. A total of 381 heads of households, or when absent the next ranking adult family member, were interviewed.
The questionnaire was based on those of previously published surveys of sylvatic rabies outbreaks 8 . The survey was conducted in three stages between February and April 2012.

The questionnaire consisted of five sections: (i) dwelling conditions, such as the presence of openings in the house, whether the construction was complete, and protective measures; (ii) sociodemographic characteristics including sex, age, health access, and active social role; (iii) type of use of health services and traditional medicine; (iv) presence and type of domestic animals, including livestock; and (v) perception of a rise in vampire bat activity (attacks/bites) relating to humans and animals.

\section{Statistical analysis}

A univariate analysis was carried out using IBM SPSS version 18 (IBM Corp., Armonk, USA). The categories and variables unfinished dwelling, access to electricity, presence of domestic animals and protective measures were then reduced and classified into clusters through multiple correspondence analyses using the SPAD package. The results are shown in Tables 1 and 2.

\section{Ethical aspects}

The study protocol was approved by the Ecuadorian Ministry of Public Health and Achuar and Shuar authorities. The participation of the heads of Households in the study was authorized by each Community's General Assembly and each interviewee participated voluntarily and signed an informed consent form.

\section{Results}

The variables and categories are shown in Table 1. Families with 10 or more members accounted for $5 \%$ of the sample, while $51.7 \%$ of families had between five and nine members and $43.3 \%$ had four or less members. The proportion of male participants was $50.3 \%$.

The mean age of participants was 36.9 years (SD 12.1), 25\% were aged under 28.1 years and $25 \%$ aged over 43.9 years. Ninety-four percent of families travelled to the health unit on foot and $40 \%$ of these families took up to two hours to complete the trip. A total of 141 households (37\%) had domestic animals and one third of these families had more than one type of animal.

Over a fifth $(21.5 \%)$ of the heads of households reported having been bitten by a bat in the last year. The average number of times that they had been bitten was 2.9 , and the length of time 
Study variables.

\begin{tabular}{|c|c|c|}
\hline Characteristic & $\mathrm{n} /$ Total & $\%$ \\
\hline \multicolumn{3}{|l|}{ Family dwelling } \\
\hline House with no openings & $131 / 381$ & 34.4 \\
\hline Unfinished house and huts & $250 / 381$ & 65.6 \\
\hline Openings present & $322 / 381$ & 84.5 \\
\hline Electricity & $178 / 381$ & 46.7 \\
\hline Generator & 79/178 & 44.2 \\
\hline Solar panels & $75 / 178$ & 41.8 \\
\hline Outdoor lighting at night against bat attacks & $63 / 381$ & 16.5 \\
\hline Protection against entry of small animals & $62 / 381$ & 16.3 \\
\hline Mosquito nets & $56 / 62$ & 90.1 \\
\hline Active social role & $164 / 381$ & 43.0 \\
\hline Health agents & $25 / 164$ & 15.2 \\
\hline Community leader & $51 / 164$ & 31.1 \\
\hline Teachers or education delegates & $81 / 164$ & 49.4 \\
\hline Female family heads & $69 / 381$ & 18.1 \\
\hline \multicolumn{3}{|l|}{ Health services } \\
\hline Used for any type of health problem & $216 / 381$ & 56.7 \\
\hline Used only in cases of severe illness & $126 / 381$ & 33.1 \\
\hline Traditional medicine only (witch-doctor) & $36 / 381$ & 9.4 \\
\hline \multicolumn{3}{|l|}{ Livestock } \\
\hline Present & $141 / 381$ & 37.0 \\
\hline Cows & $97 / 141$ & 68.8 \\
\hline Horses & $72 / 141$ & 51.1 \\
\hline Pigs & $26 / 141$ & 18.4 \\
\hline Poultry & $124 / 141$ & 87.9 \\
\hline Domestic (cats, dogs) & $93 / 141$ & 65.9 \\
\hline \multicolumn{3}{|l|}{ Perception of a rise in vampire bat activity (bites, attacks) } \\
\hline Yes & $251 / 381$ & 65.9 \\
\hline Yes, rise in humans & $88 / 251$ & 35.2 \\
\hline Yes, rise in animals & $163 / 251$ & 64.8 \\
\hline Knowledge about attacks in other communities & $138 / 381$ & 36.2 \\
\hline Reported livestock bites last month & 107/141 & 75.6 \\
\hline Reported livestock losses due to bat bites & $115 / 141$ & 81.6 \\
\hline
\end{tabular}

since the most recent attack was less than two months.

The clusters are shown in Table 2. The associated categories in cluster one are better quality housing, access to electricity, no openings in the house, presence of protective measures against entry of bats, absence of domestic animals, and the perception of a rise in bat bites among humans but not animals.

Clusters two and three include poor quality dwellings with openings, no electricity, no protective measures against bat bites, and presence of all types of domestic animals, except horses, and the perception of a rise in bat bites among animals but not among humans.

The perception of a rise in vampire bat attacks on humans is associated with better quality dwellings with no openings, and absence of domestic animals. In contrast, the opposite perception is associated with poor quality dwellings with openings and presence of domestic animals. With regard to bat activity and animals, the perception of an increase in attacks on animals is associated with poor quality dwellings with openings and presence of domestic animals. 
Table 2

Variables and categories associated with the clusters *.

\begin{tabular}{|c|c|c|c|c|c|c|c|c|}
\hline Cluster & $\begin{array}{l}\text { Access to } \\
\text { electricity }\end{array}$ & $\begin{array}{l}\text { Outdoor } \\
\text { lighting }\end{array}$ & $\begin{array}{c}\text { Active } \\
\text { protection } \\
\text { measures }\end{array}$ & $\begin{array}{c}\text { Presence of } \\
\text { livestock }\end{array}$ & Openings & $\begin{array}{l}\text { Type of } \\
\text { dwelling }\end{array}$ & $\begin{array}{c}\text { Perception of a } \\
\text { rise in vampire bat } \\
\text { attacks/bites among } \\
\text { humans }\end{array}$ & $\begin{array}{c}\text { Perception of a rise in } \\
\text { vampire bat attacks/bites } \\
\text { among animals }\end{array}$ \\
\hline 1 & Yes & Yes & Yes & No & No & $\begin{array}{l}\text { Finished } \\
\text { or house } \\
\text { without } \\
\text { openings }\end{array}$ & Yes & No \\
\hline 2 & No & No & No & $\begin{array}{c}\text { Yes, but no } \\
\text { horses. }\end{array}$ & Yes & Hut & No & Yes \\
\hline 3 & $\begin{array}{l}\text { No } \\
\text { participation } \\
\text { in the cluster }\end{array}$ & $\begin{array}{l}\text { No } \\
\text { participation } \\
\text { in the cluster }\end{array}$ & No & $\begin{array}{l}\text { Cows, } \\
\text { horses, cats, } \\
\text { poultry, dogs }\end{array}$ & Yes & $\begin{array}{l}\text { Other } \\
\text { dwellings } \\
\text { (completely } \\
\text { open house) }\end{array}$ & No & Yes \\
\hline
\end{tabular}

* The categories of the variables are "yes" or "no".

\section{Discussion and limitations}

The apparently low incidence of rabies cases in humans at national level may mask the high frequency of vampire bat attacks linked to rabies cases in specific localities. The findings of this study suggest that the lack of protective measures against the entry of bats in houses and presence of domestic animals are associated with the perception of a rise in attacks on animals and humans. Similarly, given that attacks occur at night, the use of outdoor lighting and protective measures are also associated with this perception.

The results of this study also show the negative economic impacts of bat attacks. In households that owned livestock, eight out of 10 families lost animals that died after being bitten by bats. However, it was only after the deaths of children that the authorities were spurred to respond and implement a massive post-exposure vaccination campaign.

The heads of households living in better quality housing, using protective measures against bat bites, and with no domestic animals perceived an increase bat attacks but only on humans. People who are accustomed to being bitten by bats apparently have a weaker perception of the seriousness of this problem but have a real concern about the risks to their livestock. A study carried out in Peru found an alarming degree of misinformation about rabies among the people sampled despite the fact that $90 \%$ had been bitten by a vampire bat 9 .

It should also be noted that the inhabitants of these communities were nomads until about seven decades ago and this change in lifestyle has led to changes in land use, diet and other factors which may have led to a disturbance in the balance of the local ecosystems, as described by other authors in studies carried out in the Amazon basin 8,10 . However, such changes in ecological factors are beyond the scope of this study due to the lack of comparative historical data on changes which may be attributable to specific nomadic communities. 


\section{Resumo}

Um surto de raiva silvestre foi notificado em comu nidades indígenas da Amazônia equatoriana em novembro de 2011. O objetivo deste estudo foi analisar as características do domicílio e aspectos sociodemográficos das famílias associados à percepção do aumento de mordeduras de morcegos hematófagos em humanos e gado doméstico, a fim de orientar a implementação de políticas locais de controle. Foram entrevistados 381 chefes de família das comunidades incluídas no programa de controle do surto. Entre os que possuem gado é maior a percepção de mordidas de morcego nos animais, apesar de terem também as piores condições de moradia, enquanto as famílias em melhores condições de moradia, com medidas de proteção, eletricidade e sem gado percebem um aumento nos ataques a humanos. A análise da percepção da frequência de mordidas é fundamental para incrementar a adesão às medidas de prevenção e vacinação.

Quirópteros; Raiva; Surtos de Doenças

\section{Contributors}

N. Romero contributed to study conception and design, data collection, analysis and interpretation, drafting the article, critical revision of the manuscript for important intellectual content, and the final approval of the published version. N. Escobar contributed to data collection and interpretation, drafting the article and final approval of the published version. M. Utzet contributed to data analysis and interpretation, critical revision of the manuscript for important intellectual content, and final approval of the published version of this article. M. Feijoo-Cid contributed to study conception and design, data interpretation, critical revision of the manuscript for important intellectual content, and final approval of the published version of this article. M. Martin contributed to study conception and design, data analysis and interpretation, critical revision of the manuscript for important intellectual content, and final approval of the published version of this article.

\section{Acknowledgments}

The research team is grateful to Dr. Fulvio Nedel for his contribution to reviewing the Portuguese version of this article. M. Martin is funded by the Prometeo Program -SENESCYT- Ecuador.

\section{Disclaimer}

The opinions and statements contained herein are those of the authors and should not be interpreted as reflecting the official position or opinion of the Ecuadorian Ministry of Health. 


\section{References}

1. Schneider MC, Romijn PC, Uieda W, Tamayo H, Silva DF, Belotto A, et al. Rabies transmitted by vampire bats to humans: an emerging zoonotic disease in Latin America? Rev Panam Salud Pública $2009 ; 25: 260-9$.

2. Salmon-Mulanovich G, Vasquez A, Albujar C, Guevara C, Laguna-Torres A, Salazar M, et al. Human rabies and rabies in vampire and nonvampire bat species, Southeastern Peru, 2007. Emerg Infect Dis 2009; 15:1308-11.

3. Badillo R, Mantilla JC, Pradilla G. Encefalitis rábica humana por mordedura de murciélago en un área urbana de Colombia. Biomédica (Bogotá) 2009; 29:191-203.

4. Ministerio de Salud Pública de Ecuador. Decreto de estado de emergencia sanitaria por el brote de rabia selvática. Decreto ejecutivo no 963 de 8 de diciembre del 2011. Quito: Ministerio de Salud Pública de Ecuador; 2011.

5. Romero-Sandoval N, Parra C, Gallegos G, Guanopatín A, Campaña MF, Haro M, et al. Haematophagous bat bites in Ecuadorian Amazon: characterisation and implications for sylvatic rabies prevention. Public Health Action 2013; 3:85-9.
6. Paredes C. Situação de los brotes recientes en el Equador. http://www1.paho.org/Spanish/AD/ DPC/VP/rabia-murcielagos-paredes.pdf (accessed on 02/Apr/2012).

7. Koprowski H. Rabies in the face of the 21st century. Zoonoses Public Health 2009; 56:258-61.

8. Schneider MC. Rabia humana transmitida por murciélago hematófago en Brasil: modelo de transmisión y acciones de control [Tesis de Doctorado]. Cuernavaca: Instituto Nacional de Salud Pública; 1996.

9. Gómez-Benavides J, Laguna-Torres VA, Recuenco $\mathrm{S}$. The real significance of being bitten by a hematophagous bat in indigenous communities in the remote Peruvian Amazon. Rev Peru Med Exp Salud Pública 2010; 27:657-8.

10. Gilbert AT, Petersen BW, Recuenco S, Niezgoda M, Gómez J, Laguna-Torres VA, et al. Evidence of rabies virus exposure among humans in the Peruvian Amazon. Am J Trop Med Hyg 2012; 87:206.

Submitted on 20/Mar/2013

Final version resubmitted on 29/Oct/2013 Approved on 04/Nov/2013 